\title{
Prophage induction of indigenous marine lysogenic bacteria by environmental pollutants
}

\author{
Pamela K. Cochran, Christina A. Kellogg, John H. Paul* \\ Department of Marine Science, University of South Florida, 140 th Ave. South, St. Petersburg, Florida 33701, USA
}

\begin{abstract}
Lysogenic bacteria may be abundant components of bacterial assemblages in marine waters. The tremendous number of viruses found in estuarine and other eutrophic environments may be the result in part of induction of prophages. Mitomycin $\mathrm{C}$ is the inducing agent of choice for prophage induction; however this is not naturally found in the marine environment. We determined the capability of environmentally important pollutants to effect prophage induction in natural populations of marine bacteria. We investigated Aroclor 1248, a PCB mixture, bunker $\mathrm{C}$ fuel oil $\# 6$, and a pesticide mixture as inducing agents for natural bacterial communities from the Gulf of Mexico. Mitomycin $\mathrm{C}$ was also employed as a positive control for induction. Induction was determined as a significant increase in viral direct counts compared to control and ranged from 149 to $1336 \%$ of the controls. Twothirds of the environments sampled showed prophage induction by one of the methods utilized, with the PCB mixture and Aroclor 1248 giving the highest percent efficiency $175 \%$ ) of induction. This study shows that many environmentally important pollutants may be inducing agents for natural lysogenic viral production in the marine environment.
\end{abstract}

KEY WORDS: Marine bacteriophage - Lysogeny Gulf of Mexico Pollution

\section{INTRODUCTION}

Viruses are among the most abundant microorganisms in the surface waters of the world's oceans, and it is vital to understand their role in the ecology of natural microbial populations. Viral abundance has been found to range from $10^{4} \mathrm{ml}^{-1}$ in oligotrophic and deep sea environments to over $10^{8} \mathrm{ml}^{-1}$ in coastal and estuarine environments (Sieburth et al. 1988, Bergh et al. 1989, Bratbak et al. 1990, Paul et al. 1991, Fuhrman \& Suttle 1993). Because of the obligate parasitic nature of viruses it is suggested that they play a dynamic role in bacterial and phytoplankton mortality in the ocean (Fuhrman \& Suttle 1993, Fuhrman \& Noble 1995, Weinbauer \& Peduzzi 1995) and a major role in the microbial loop ecosystem. It has also been suggested that a significant proportion of the viral population participates in lysogenic interactions with bacteria in the marine environment (Bratbak et al. 1990, 1992, Heldal

\footnotetext{
-Addressee for correspondence.

E-mail: jpaul@seas.marine.usf.edu
}

\& Bratbak 1991, Thingstad et al. 1993). Yet, only a few studies have looked at this in detail (Wilcox \& Fuhrman 1994, Weinbauer \& Suttle 1996).

Lysogeny is the process by which a virus maintains a stable symbiosis with its host, and is the alternative to lytic replication. The viral DNA, once injected into the host, is termed a prophage and will replicate during normal host cell division. The lysogenic state may continue for many generations until the prophage is spontaneously activated or until induction by mutagenic agents such as ultraviolet $\left(U V-C_{i}<300 \mathrm{~nm}\right)$ radiation or mitomycin C (Ackermann \& DuBow 1987), neither of which are found naturally in the marine environment.

In a previous study, we reported that $43 \%$ of marine bacterial isolates examined were inducible by mitomycin C (Jiang \& Paul 1994). Since less than $1 \%$ of marine bacteria are cultivable by standard plating techniques, we have investigated the proportion of lysogens in natural bacterial populations in the marine environment by prophage induction (Jiang \& Paul 1996). Utilizing this approach we have been able to extend this study to include natural bacterial popula- 
tions from an estuarine environment. From this we have determined that 2.1 to $21.1 \%$ of indigenous bacteria contained inducible prophage as indicated by significant increases in viral direct counts over uninduced controls (Cochran \& Paul in press).

Polychlorinated biphenyls (PCBs) are a class of synthetic chlorinated aromatic compounds that have been used primarily in the electrical industry in capacitors and transformers and also as de-dusting agents and pesticides (Erikson 1986). While the total amount of PCBs produced yearly has declined since the 1970s (Barrie et al. 1992), this does not necessarily imply that the toxicological threat posed by these compounds has also decreased. PCBs are insoluble in water and few organisms can break down halogenated aromatics. Therefore, the presence of PCBs in the environment has become a growing concern because of their toxicity, mutagenicity, and tendency to bioaccumulate (Bedard \& Haberl 1990). Routes by which PCBs and pesticides enter the marine environment are numerous and include industrial and municipal point sources, storm water, combined sewer overflows, atmospheric deposition, and other non-point sources (McElroy et al. 1989).

We have previously investigated the capacity of polynuclear aromatic hydrocarbons to cause induction of natural prophage populations (Jiang \& Paul 1996). Here we report the ability of environmentally important pollutants to induce indigenous lysogenic bacteria from a number of environments. The pollutants examined include Aroclor 1248 (the maximum toxicity of $\mathrm{PCB}$ ), a $\mathrm{PCB}$ mixture, a pesticide mixture, and the hydrocarbon bunker $C$ fuel oil \#6 as possible inducing agents. Mitomycin $C$, a known inducing agent, was also utilized as a control for prophage induction.

\section{MATERIAL AND METHODS}

Sampling sites. Water samples were collected during a research cruise in the Gulf of Mexico during September 1996 on the RV 'Pelican' Station locations for the Pelican cruise are indicated in Fig. 1. Subsurface and deep water samples were collected with 201 Niskin bottles, and surface waters were collected by pumping directly into acid-washed $20 \mathrm{l}$ carboys. All samples were processed immediately.

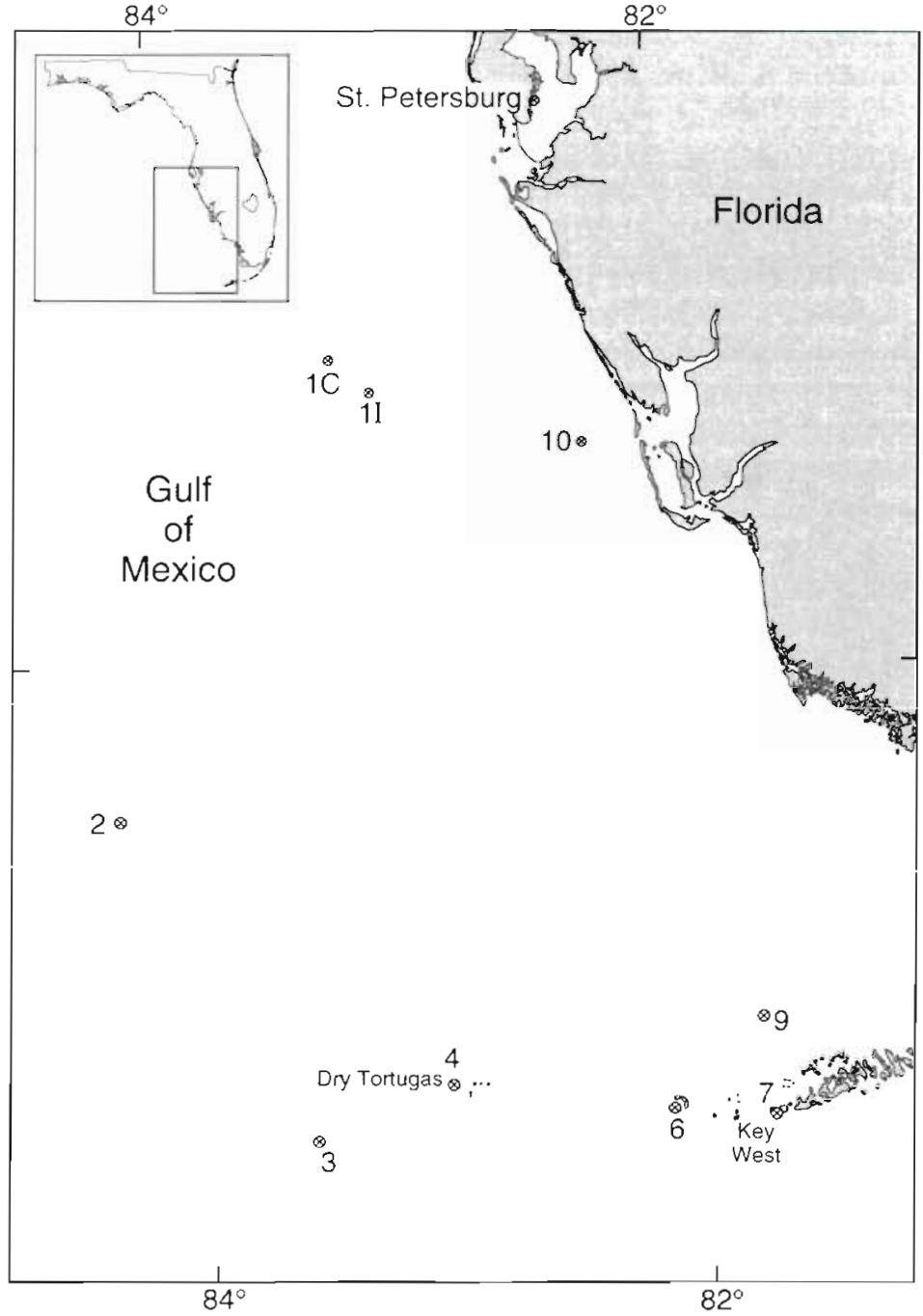

Fig. 1. Water samples were collected in September of 1996 during a research cruise in the Gulf of Mexico aboard the RV 'Pelican' Sampling locations are indicated on the map above. Stn $1 \mathrm{C}: 26^{\circ} 58^{\prime} \mathrm{N}, 83^{\circ} 21^{\prime} \mathrm{W}_{\text {i }}$ Stn 1I: $26^{\circ} 52^{\prime} N, 83^{\circ} 13^{\prime} W_{i} S t n .2: 25^{\circ} 32^{\prime} N, 84^{\circ} 05^{\prime} W_{i} \operatorname{Stn} 3: 24^{\circ} 13^{\prime} N$, $83^{\circ} 24^{\prime} W_{i}$ Stn 4: African Reef; Stn 6: Marquesas; Stn 7 : Key West Harbor; Stn 9: Florida Bay; Stn 10: Charlotte Harbor

Induction of lysogenic bacteria by chemical inducing agents. For each water sample, 20 to $40 \mathrm{l}$ was either concentrated by a Membrex Rotary Biofiltration Device to a final volume of 50 to $70 \mathrm{ml}$ (Paul et al. 1991, Jiang et al. 1992) or left unconcentrated. The samples were then subdivided and either treated by adding one of the following reagents: mitomycin $C$ (range from 0.05 to $1.0 \mathrm{\mu g} \mathrm{ml}^{-1}$ ), a pesticide mixture (range from 0.01 to $\left.1.0 \mu \mathrm{g} \mathrm{ml}^{-1}\right)$, a PCB mixture $\left(1.0 \mu \mathrm{g} \mathrm{ml}^{-1}\right)$, Aroclor $1248\left(1.0 \mu \mathrm{g} \mathrm{ml}^{-1}\right)$, or bunker $\mathrm{C}$ fuel oil \#6 (range from 0.02 to $\left.10 \mu \mathrm{g} \mathrm{m}^{-1}\right)$, or left untreated. The commercial name of $\mathrm{PCB}$ is Aroclor and a PCB mixture with $48 \%$ chlorine by mass is called Aroclor 1248. PCB 
toxicity depends on chlorines being present in the ortho positions and the toxicity reaches a maximum in a 1248 Aroclor. Aroclor 1248, the PCB mixture and the pesticide mixture were all obtained in $1 \mathrm{ml}$ stock solutions from Ultra Scientific, North Kingstawn, RI, USA. The pesticide mixture contained the following agents: $1,2,3,4,5,6$-hexachlorocyclohexane, $\alpha$-isomer (alpha$\mathrm{BHC}) ; \quad 1,2,3,4,5,6$-hexachlorocyclohexane, $\gamma$-isomer (gamma-BHC; lindane); 2,2-bis(4-chlorophenyl)-1,1dichloroethane (DDD); 1,1-bis(4-chlorophenyl)-2, 2,2trichloroethane (DDT); dieldrin; endosulfan I; endrin; heptochlor; methoxychlor; 2,4,5,6-tetrachloro-m-xylene; decachlorobiphenyl. The PCB mixture consisted of 8 different chlorinated biphenyl compounds: 2-chlorobiphenyl; 2,3-dichlorobiphenyl; 2, 4,5-trichlorobiphenyl; $2,2^{\prime}, 4,4^{\prime}$-tetrachlorobiphenyl; 2, 2', 3'4,6-pentachlorobiphenyl; $2,2^{\prime}, 4,4^{\prime}, 5,6^{\prime}$-hexachlorobiphenyl; $2,2^{\prime}, 3,3^{\prime}, 4$, 4',6-heptachlorobiphenyl; 2, 2',3,3',4,5',6,6'-octachlorobiphenyl. The bunker $C$ fuel oil \#6 was obtained from Texaco, Inc. and dissolved in hexane (Fisher Chemical, Pittsburgh, PA, USA) to make a stock solution. The organic solvent in each of the chemical agents was then evaporated in a fume hood after the desired amount of the chemical was added to clean amber glass bottles, leaving only the chemical behind. Water samples collected from a number of stations were added to the chemical-containing bottles on the cruise. All samples were well mixed and incubated in the dark for $24 \mathrm{~h}$ before fixing with $2 \%$ glutaraldehyde (transmission electron microscopy, 'TEM', grade). Samples were then stored at $4^{\circ} \mathrm{C}$ until viral direct counts (VDC) and bacterial direct counts (BDC) were performed back at the laboratory.

Direct enumeration of viruses and bacteria. VDC for the unconcentrated samples were determined by the ultracentrifugation method of Bergh et al. (1989). Viral abundance for the Membrex-concentrated samples were performed as described previously by Paul et al. (1991). Two grids per sample, 2 windows per grid, and 30 random fields per window were counted at $50000 x$ magnification using a Hitachi 7100 transmission electron microscope (TEM). Photomicrographs of bacteria containing mature phage were taken at a magnification of 50000 to 80000 times.

Samples for bacterial direct counts were stained with 2,4-diamidino-2-phenylindole (DAPI; Sigma Chemical Co., St. Louis, MO, USA) overnight and filtered onto Irgalan black-stained $25 \mathrm{~mm}, 0.2 \mu \mathrm{m}$ Nuclepore filters and counted by epifluorescence microscopy as described elsewhere (10 grids per slide, 3 slides per sample; Paul 1982). Samples from the Membrex-concentrated water were first diluted with $0.2 \mu \mathrm{m}$ filtered artificial seawater and then stained with DAPI.

Chlorophyll a determination. Samples for chlorophyll a (chl a) were filtered in triplicate through What- man GF/F filters and the filters were stored at $-20^{\circ} \mathrm{C}$ until further analysis. The chl a was extracted in $100 \%$ methanol and quantified fluorometrically using a Turner Designs fluorometer (Holm-Hansen \& Riemann 1978).

${ }^{14} \mathrm{C}$ carbon fixation. Rates of carbon fixation were measured by the ${ }^{14} \mathrm{C}-\mathrm{HCO}_{3}$-technique as in Strickland \& Parsons (1968) as modified by Carpenter \& Lively (1980). Counting efficiency was determined by scintillation counting of a ${ }^{14} \mathrm{C}$ standard (Wang et al. 1975). Sample carbonate alkalinity and total carbon dioxide content were determined by titration with $0.01 \mathrm{~N} \mathrm{HCl}$ (Strickland \& Parsons 1968). Total carbon dioxide and incorporated ${ }^{14} \mathrm{C}$ were used to determine the rate of carbon fixation for each sample.

Statistical analysis. Two sample comparison by $t$-test on parallel samples was performed using Statgraphics software (Manugistics Inc., Rockville, MD, USA). Statistical comparisons for VDC were generated from the average of 4 grids per sample. Statistical comparisons for BDC were generated from the average of 3 replicate slides for each sample.

\section{RESULTS}

Table 1 presents the environmental parameters determined at each station along the cruise transect. These include temperature, salinity, chlorophyll a concentrations, primary production, and viral and bacterial direct counts. Surface water temperatures remained predominately around $30.0^{\circ} \mathrm{C}$. The lower water temperatures $\left(22\right.$ and $24.2^{\circ} \mathrm{C}$ ) were obtained at the subsurface chl a maximum from Stns 2 and 3, where depth profile sampling was conducted. From these, chlorophyll concentrations of 5.78 and $3.70 \mu \mathrm{g} \mathrm{l}^{-1}$ were measured (Stns 2 and 3, respectively). The high chl $a$ concentration obtained from Stn 2 also coincided with high rates of photosynthetic carbon fixation $1.52 \mu \mathrm{g} \mathrm{C}$ $\mathrm{l}^{-1} \mathrm{~h}^{-1}$ ) present at this depth (the subsurface chlorophyll maximum). The lowest chlorophyll a concentrations were obtained from Stn $1\left(0.07\right.$ and $\left.0.10 \mu \mathrm{g} \mathrm{l}^{-1}\right)$, reflecting the oligotrophic nature of surface waters in that environment. The low virus-to-bacterium ratios (range from 0.33 to 13.57; Hara et al. 1991, Wommack et al. 1992) obtained at each station were the result of low overall viral abundance when compared to bacterial numbers. Only at 4 stations did the virus numbers exceed the bacteria present in the water column.

It is assumed that primary production drives the entire system and therefore high levels of primary production should correspond to an active mesotrophic microbial community and increase the number of inducible lysogens. At 5 of the 8 stations where primary production was measured (Gulf of Mexico Stns 1I, 2, and 3; Key 
Table 1. Environmental parameters measured at each station along the cruise route. BDC: bacterial direct counts; VDC: viral direct counts; VLP: virus-Iike partıcles

\begin{tabular}{|c|c|c|c|c|c|c|}
\hline Station & $\begin{array}{l}\text { Temperature } \\
\left({ }^{\circ} \mathrm{C}\right)\end{array}$ & $\begin{array}{l}\text { Salinity } \\
\text { (ppt) }\end{array}$ & $\begin{array}{c}\text { BDC } \\
\text { (cells } \pm \text { SE ml-1) }\end{array}$ & $\begin{array}{c}\mathrm{VDC} \\
\left(\mathrm{VLP} \pm \mathrm{SE} \mathrm{mL}^{-1}\right)\end{array}$ & $\begin{array}{c}\text { Chl a } \\
\left(\mu \mathrm{g} \mathrm{l}^{-1}\right)\end{array}$ & $\begin{array}{l}\text { Primary production } \\
\qquad\left(\mu \mathrm{g} \mathrm{Cl}^{-1} \mathrm{~h}^{-1}\right)\end{array}$ \\
\hline Gulf of Mexico, Stn 1C & 30.1 & 36.1 & $1.93 \pm 0.12 \times 10^{5}$ & $2.62 \pm 0.81 \times 10^{6}$ & 0.07 & 0.295 \\
\hline Gulf of Mexico, Stn II & 30.0 & 36.1 & $1.94 \pm 0.01 \times 10^{5}$ & $1.58 \pm 0.25 \times 10^{5}$ & 0.10 & 0.352 \\
\hline Gulf of Mexico, Stn $2(58 \mathrm{~m}$ & 22.0 & 36.5 & $1.02 \pm 0.17 \times 10^{5}$ & $4.08 \pm 1.40 \times 10^{4}$ & 5.78 & 1.52 \\
\hline Gulf of Mexico, Stn $3185 \mathrm{~m}$ & 24.2 & 36.8 & $3.31 \pm 0.08 \times 10^{4}$ & $1.67 \pm 1.32 \times 10^{5}$ & 3.70 & 0.433 \\
\hline African Reef, Dry Tortugas & 30.0 & 35.6 & $1.12 \pm 0.06 \times 10^{5}$ & $1.05 \pm 0.24 \times 10^{6}$ & 0.38 & 0.918 \\
\hline Marquesas & 30.0 & 36.0 & $1.12 \pm 0.06 \times 10^{6}$ & $6.58 \pm 3.60 \times 10^{5}$ & 0.63 & 1.48 \\
\hline Key West Harbor & 31.0 & 36.2 & $9.00 \pm 3.30 \times 10^{5}$ & $2.99 \pm 2.60 \times 10^{5}$ & nd & nd \\
\hline Florida Bay & 30.1 & 36.3 & $4.06 \pm 0.82 \times 10^{5}$ & $1.19 \pm 0.50 \times 10^{6}$ & 0.72 & 3.59 \\
\hline Charlotte Harbor & 29.1 & 35.2 & $1.63 \pm 0.30 \times 10^{6}$ & $6.18 \pm 0.30 \times 10^{5}$ & 1.08 & 5.43 \\
\hline \multicolumn{7}{|l|}{ nd: not determined } \\
\hline
\end{tabular}

West harbor, and Florida Bay), high rates of carbon fixation corresponded to a lysogenic response. Stns 1I, 2, and 3, along with the Marquesas and Florida Bay, all had relatively active microbial communities with primary production values ranging from 0.35 to $3.59 \mu \mathrm{g} \mathrm{Cl}^{-1}$ $\mathrm{h}^{-1}$ (Table 1). The few exceptions to this were Stn 1C, African Reef and the Charlotte Harbor sample which contained the highest primary production values (5.43 $\mu \mathrm{g} \mathrm{Cl}^{-1} \mathrm{~h}^{-1}$ ) measured. While the African Reef and Charlotte Harbor samples did fall within the range

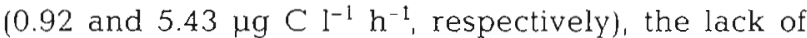
inducible prophage is probably best explained by the toxicity of the chemicals used (see 'Discussion').

Table 2 shows the results of induction of indigenous lysogenic bacteria by treatment with a range of mitomycin $\mathrm{C}$ concentrations. When combined with Tables 3 $\& 4$, we determined that 5 of the 9 stations sampled showed significant increases in VDC in response to the addition of mitomycin C. VDC in the induced samples ranged from a 172 to a $1311 \%$ increase over the control. Most samples that showed significant increases in VDC also showed significant decreases in BDC (38 to $80 \%$ of the control). The mitomycin $C$ range employed in the study was from 0.05 to $1.0 \mu \mathrm{g} \mathrm{ml}^{-1}$ In the West Florida Shelf environment (Stn 1C), none of the concentrations tested resulted in an induction response, whereas in the subsurface chl a maximum (SCM) environment each concentration utilized resulted in significant increases in viral abundance over the control value (206 to $375 \%$ increases). We hypothesize that the SCM (Stn 2) had a greater overall microbiological activity than the surface station (1C) as reflected in differences in carbon fixation rates (Table 1). However, no measure of heterotrophic bacterial community activity was made.

Table 2. Induction of indigenous lysogenic bacteria from the Gulf of Mexico by a range of mitomycin C (MC) concentrations. For viral and bacterial direct counts, values for controls are given as virus or bacteria \pm standard error per ml, respectively, values for inducing agents as \% of control. (S) significance and (I) insignificance at $95 \%$ confidence; na: not applicable

\begin{tabular}{|c|c|c|c|}
\hline Sample & $\begin{array}{l}\text { Viral direct count } \\
\text { (control: virus } \pm \mathrm{SE} \mathrm{\textrm { } \mathrm { I } ^ { - 1 }} \\
\text { agents: } \% \text { of control) }\end{array}$ & 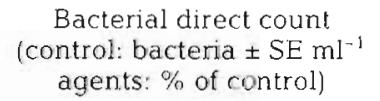 & $\begin{array}{l}\% \text { of lysogenic bac- } \\
\text { teria based on mean } \\
\text { burst size }(30)\end{array}$ \\
\hline \multicolumn{4}{|c|}{ Gulf of Mexico Stn $1 C_{1}$ concentrated } \\
\hline Control & $1.31 \pm 0.43 \times 10^{5}$ & $1.93 \pm 0.12 \times 10^{5}$ & \\
\hline $0.05 \mu \mathrm{g} \mathrm{ml}^{-1} \mathrm{MC}$ & $45(\mathrm{I})$ & $52(S)$ & na \\
\hline $0.1 \mu \mathrm{g} \mathrm{ml}^{-1} \mathrm{MC}$ & $47(\mathrm{l})$ & $97(\mathrm{I})$ & na \\
\hline $0.5 \mu \mathrm{g} \mathrm{ml} \mathrm{m}^{-1} \mathrm{MC}$ & $110(\mathrm{l})$ & $92(I)$ & na \\
\hline $1.0 \mu \mathrm{gml}^{-1} \mathrm{MC}$ & 1.39 (I) & 81. (1) & na \\
\hline \multicolumn{4}{|c|}{ Guif of Mexico Stn 1C, non-concentrated } \\
\hline Control & $2.56 \pm 2.5 \times 10^{5}$ & $2.15 \pm 0.10 \times 10^{6}$ & \\
\hline $0.05 \mu \mathrm{g} \mathrm{ml}^{-1} \mathrm{MC}$ & N/A (I) & $31(\mathrm{~S})$ & na \\
\hline $0.1 \mu \mathrm{g} \mathrm{ml}^{-1} \mathrm{MC}$ & 67 (I) & 38 (S) & na \\
\hline $0.5 \mu \mathrm{g} \mathrm{ml}{ }^{-1} \mathrm{MC}$ & 15 (I) & 33 (S) & na \\
\hline $1.0 \mu \mathrm{g} \mathrm{ml}^{-1} \mathrm{MC}$ & N/A (I) & $30(S)$ & na \\
\hline \multicolumn{4}{|c|}{ Gulf of Mexico Stn 2, chl a max. concentrated } \\
\hline Control & $4.08 \pm 1.40 \times 10^{4}$ & $1.02 \pm 0.17 \times 10^{5}$ & \\
\hline $0.05 \mu \mathrm{g} \mathrm{ml}^{-1} \mathrm{MC}$ & $375(\mathrm{~S})$ & $79(1)$ & 3.67 \\
\hline $0.1 \mu \mathrm{g} \mathrm{ml}^{-1} \mathrm{MC}$ & $210(S)$ & $94(\mathrm{I})$ & 1.46 \\
\hline $0.5 \mu \mathrm{g} \mathrm{ml}^{-1} \mathrm{MC}$ & $206(S)$ & 107 (I) & 1.42 \\
\hline $1.0 \mu \mathrm{g} \mathrm{ml}^{-1} \mathrm{MC}$ & 309 (S) & 117 (I) & 2.78 \\
\hline
\end{tabular}


Table 3. Induction of indigenous lysogenic bacteria from the Gulf of Mexico by environmentally important pollutants. For viral and bacterial direct counts, values for controls are given as virus or bacteria \pm standard error per ml, respectively, values for inducing agents as \% of control. (S) significance and (I) insignificance at $95 \%$ confidence; na: not applicable. Concentrations

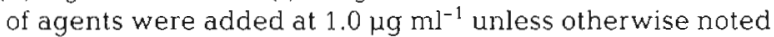

\begin{tabular}{|c|c|c|c|}
\hline Sample & $\begin{array}{l}\text { Viral direct count } \\
\text { (control: virus } \pm \mathrm{SE} \mathrm{ml}{ }^{-1} \\
\text { agents: \% of control) }\end{array}$ & $\begin{array}{l}\text { Bacterial direct count } \\
\text { (control: bacteria } \pm \mathrm{SE} \mathrm{ml} l^{-1} \\
\text { agents: } \% \text { of control) }\end{array}$ & $\begin{array}{c}\% \text { of lysogenic bac- } \\
\text { teria based on mean } \\
\text { burst size }(30)\end{array}$ \\
\hline \multicolumn{4}{|c|}{ Gulf of Mexico Stn 1I, concentrated } \\
\hline Control & $1.58 \pm 0.25 \times 10^{5}$ & $1.94 \pm 0.01 \times 10^{5}$ & \\
\hline Mitomycin C & $172(\mathrm{~S})$ & $80(\mathrm{~S})$ & 1.96 \\
\hline Pesticide mix & 166 (S) & $126(\mathrm{I})$ & 1.79 \\
\hline PCB mix & $162(\mathrm{~S})$ & $90(\mathrm{I})$ & 1.68 \\
\hline Aroclor 1248 & $149(\mathrm{~S})$ & 78 (S) & 1.32 \\
\hline \multicolumn{4}{|l|}{ African Reef, concentrated } \\
\hline Control & $1.05 \pm 0.06 \times 10^{6}$ & $1.12 \pm 0.06 \times 10^{5}$ & \\
\hline Mitomycin C & $69(\mathrm{I})$ & $137(1)$ & na \\
\hline Pesticide mix & 33 (I) & 128 (I) & na \\
\hline PCB mix & 50 (I) & $274(\mathrm{I})$ & na \\
\hline Aroclor 1248 & $120(\mathrm{I})$ & 215 (I) & na \\
\hline \multicolumn{4}{|c|}{ Key West Harbor, non-concentrated } \\
\hline Control & $2.99 \pm 2.60 \times 10^{5}$ & $9.00 \pm 3.30 \times 10^{5}$ & \\
\hline Mitomycin C & $408(\mathrm{~S})$ & $61(\mathrm{I})$ & 3.41 \\
\hline PCB mix & 421 (S) & $133(1)$ & 3.56 \\
\hline Aroclor 1248 & $1013(\mathrm{~S})$ & $81(\pi)$ & 10.11 \\
\hline Bunker C oil & $334(\mathrm{~S})$ & $45(\mathrm{I})$ & 2.60 \\
\hline \multicolumn{4}{|l|}{ Florida Bay, non-concentrated } \\
\hline Control & $1.19 \pm 0.50 \times 10^{6}$ & $4.06 \pm 0.82 \times 10^{5}$ & \\
\hline Mitomycin C & $1050(\mathrm{~S})$ & $67(1)$ & 92.86 \\
\hline Pesticide mix & 1336 (S) & $124(\mathrm{I})$ & 120.77 \\
\hline PCB mix & 275 (S) & 183 (I) & 17.08 \\
\hline Aroclor 1248 & $494(\mathrm{~S})$ & 167 (I) & 38.51 \\
\hline \multicolumn{4}{|l|}{ Marquesas, non-concentrated } \\
\hline Control & $6.58 \pm 3.60 \times 10^{5}$ & $1.12 \pm 0.06 \times 10^{6}$ & \\
\hline Mitomycin C & $130(\mathrm{I})$ & $41(\mathrm{~S})$ & na \\
\hline $0.01 \mu \mathrm{g} \mathrm{ml}^{-1}$ pesticide mix & $90(\mathrm{I})$ & 262 (I) & na \\
\hline $0.1 \mathrm{~kg} \mathrm{~m}^{-1}$ pesticide mix & $178(\mathrm{I})$ & 165 (I) & na \\
\hline $1.0 \mu \mathrm{g} \mathrm{m}^{-1}$ pesticide mix & 207 (S) & 211 (I) & 2.09 \\
\hline
\end{tabular}

Table 4. Induction of indigenous lysogenic bacteria from the Gulf of Mexico by a range of bunker C fuel oil \#6 concentrations. For viral and bacterial direct counts, values for controls are given as virus or bacteria \pm standard error per ml, respectively, values for inducing agents as \% of control. (S) significance and (l) insignificance at $95 \%$ confidence; na: not applicable

\begin{tabular}{|c|c|c|c|}
\hline Sample & $\begin{array}{l}\text { Viral direct count } \\
\text { (control: virus } \pm \mathrm{SE} \mathrm{ml} \mathrm{m}^{-1} \\
\text { agents: \% of control) }\end{array}$ & $\begin{array}{l}\text { Bacterial direct count } \\
\text { (control: bacteria } \pm \mathrm{SE} \mathrm{ml} \mathrm{m}^{-1} \\
\text { agents: } \% \text { of control) }\end{array}$ & $\begin{array}{c}\% \text { of lysogenic bac- } \\
\text { teria based on mean } \\
\text { burst size }(30)\end{array}$ \\
\hline \multicolumn{4}{|c|}{ Gulf of Mexico Stn 11, concentrated } \\
\hline Control & $1.58 \pm 0.25 \times 10^{5}$ & $1.94 \pm 0.01 \times 10^{5}$ & \\
\hline Mitomycin C & $172(\mathrm{~S})$ & $80(\mathrm{~S})$ & 1.96 \\
\hline $0.1 \mu \mathrm{g} \mathrm{ml}^{-1}$ Bunker $\mathrm{C}$ oil & 4 (I) & 75 (S) & na \\
\hline $1.0 \mu \mathrm{g} \mathrm{ml}^{-1}$ Bunker $\mathrm{C}$ oil & 7 (I) & $82(\mathrm{l})$ & na \\
\hline $10.0 \mu \mathrm{g} \mathrm{ml}^{-1}$ Bunker $\mathrm{C}$ oil & 11 (I) & 73 (S) & na \\
\hline \multicolumn{4}{|c|}{ Gulf of Mexico Stn 3, chl a max. concentrated } \\
\hline Control & $1.67 \pm 1.32 \times 10^{5}$ & $3.31 \pm 0.08 \times 10^{4}$ & \\
\hline Mitomycin C & $1311(\mathrm{~S})$ & $118(\mathrm{I})$ & 10.23 \\
\hline $0.02 \mu \mathrm{g} \mathrm{ml}^{-1}$ Bunker $\mathrm{C}$ oil & $45(\mathrm{I})$ & 101 (I) & na \\
\hline 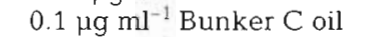 & $76(\mathrm{I})$ & $118(\mathrm{I})$ & na \\
\hline $1.0 \mu \mathrm{g} \mathrm{ml}^{-1}$ Bunker $\mathrm{C}$ oil & $44(1)$ & $72(\mathrm{~S})$ & na \\
\hline \multicolumn{4}{|c|}{ Charlotte Harbor, non-concentrated } \\
\hline Control & $6.18 \pm 3.10 \times 10^{5}$ & $1.63 \pm 0.30 \times 10^{6}$ & \\
\hline Mitomycin C & $48(\mathrm{I})$ & $38(\mathrm{~S})$ & na \\
\hline $0.1 \mu \mathrm{g} \mathrm{ml}^{-1}$ Bunker $\mathrm{C}$ oil & 201 (I) & $166(\mathrm{I})$ & na \\
\hline $1.0 \mu \mathrm{g} \mathrm{ml}^{-1}$ Bunker C oil & 79 (1) & $154(1)$ & na \\
\hline $10.0 \mu \mathrm{g} \mathrm{ml}^{-1}$ Bunker C oil & $468(\mathrm{I})$ & 58 (I) & na \\
\hline
\end{tabular}


Environmentally important pollutants were also used to induce lysogenic bacteria in shelf and coastal environments from the Gulf of Mexico in both Membrex-concentrated and unconcentrated water samples. In 3 out of the 4 environments sampled for this experiment, all 4 chemical agents utilized (mitomycin C, Aroclor 1248, PCB mixture, and pesticide mixture) resulted in prophage induction (Table 3 ), with significant increases in viral abundance over the control observed. The greatest increases in viral abundance were measured at the Florida Bay station, with a one order of magnitude increase in virus numbers observed after the addition of the pesticide mixture (1336\% increase) and mitomycin C (1050\% increase).

The pesticide mixture was also examined at varying concentrations $(0.01$ to $1.0 \mathrm{\mu g}$ $\mathrm{ml}^{-1}$ ) from water samples collected at the Marquesas station (Table 3). At the 0.01 and $0.1 \mu \mathrm{g} \mathrm{ml}^{-1}$ concentrations, no prophage inductions were observed. However when the pesticide mixture was increased to $1.0 \mu \mathrm{g} \mathrm{ml} \mathrm{m}^{-1}$, virus numbers increased significantly over the control (209\%) and induction was measured.

Bunker C fuel oil \#6 (Table 4) was examined for its ability to induce lysogenic bacteria at Key West Harbor, Charlotte Harbor, the chl a maximum (Stn 3) and the surface waters of the Gulf of Mexico (Stn 1I), at lower concentrations $\left(0.02\right.$ to $\left.10 \mu \mathrm{g} \mathrm{ml}^{-1}\right)$ than previously reported (Jiang \& Paul 1996). Prophage induction could only be detected at the Key West Harbor station using a bunker $\mathrm{C}$ fuel oil concentration of $1.0 \mu \mathrm{g} \mathrm{ml}^{-1}$ (Tables 3 \& 4). The remaining stations sampled resulted in no prophage induction even though mitomycin $\mathrm{C}$, employed as a control for prophage induction,
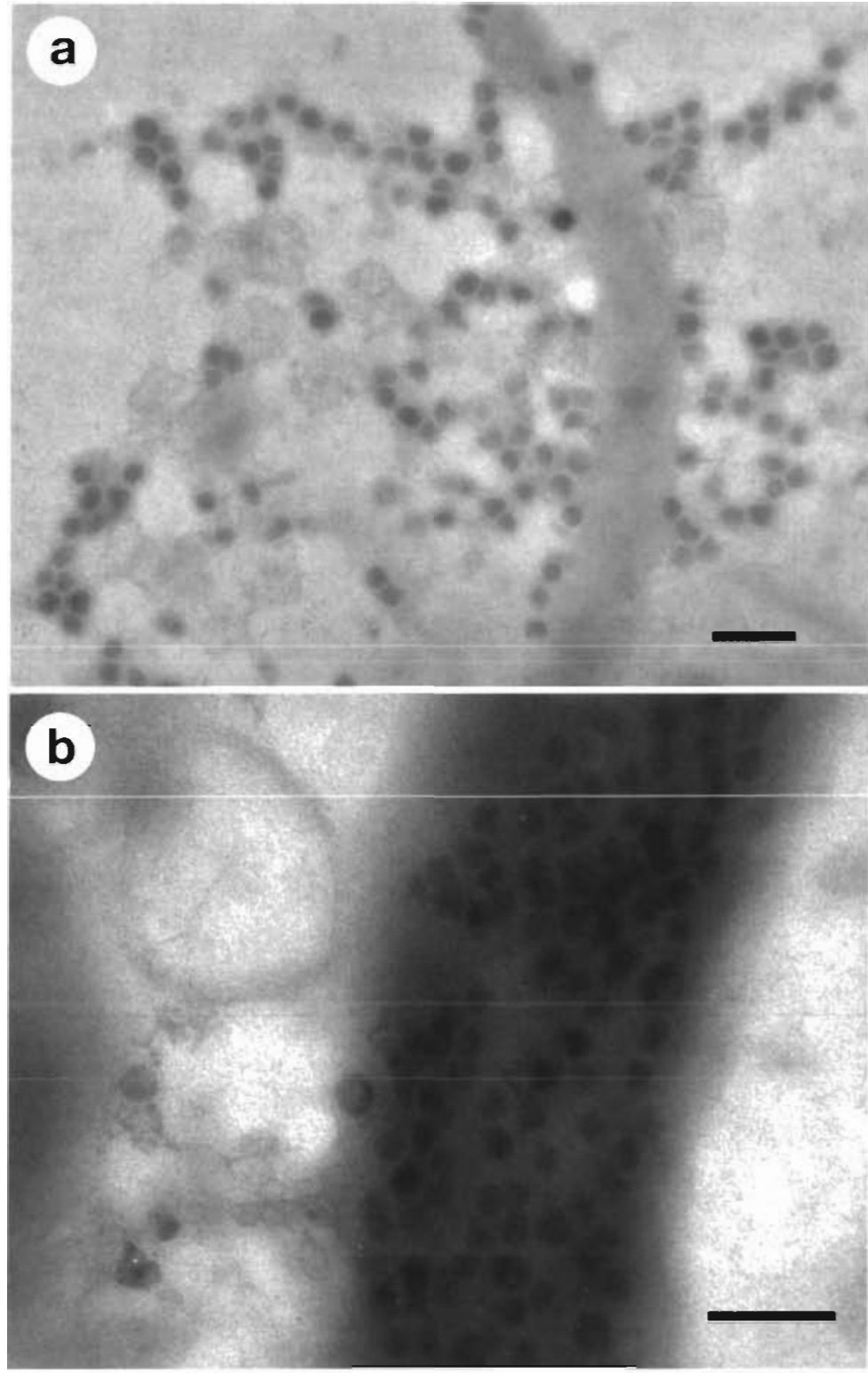

Fig. 2. Electron micrographs of phage-like particies after treatment with (a) mitomycin $C$ and (b) the pesticide mixture. Photomicrographs of bacteria containing mature phage were taken at a magnification of 50000 to 80000 times. Scale bar $=0.2 \mu \mathrm{m}$
Table 5. Efficiency of inducing agents for the induction of indigenous marine lysogens. Concentrations utilized: Mitomycin C, $0.01,0.1,0.5,1.0 \mu \mathrm{g} \mathrm{ml}^{-1}$; PCB mixture, $1.0 \mu \mathrm{g} \mathrm{ml}^{-1}$; Aroclor $1248,1.0 \mu \mathrm{g} \mathrm{ml}^{-1}$; pesticide mixture, $0.01,0.1$, $1.0 \mu \mathrm{g} \mathrm{ml}^{-1}$; bunker $\mathrm{C}$ fuel oil $\# 6,0.02,0.1,1.0,10.0 \mu \mathrm{g} \mathrm{ml}^{-1}$

\begin{tabular}{|lcccc|}
\hline Inducing agent & $\begin{array}{c}\text { No. of expts } \\
\text { performed }\end{array}$ & $\begin{array}{c}\text { No. of samples } \\
\text { induced }\end{array}$ & $\begin{array}{c}\text { Mean \% viral } \\
\text { increase }\end{array}$ & $\begin{array}{c}\text { Efficiency } \\
(\%)\end{array}$ \\
\hline Mitomycin C & 15 & 9 & 581 & 60 \\
PCB mix & 4 & 3 & 286 & 75 \\
Aroclor 1.248 & 4 & 3 & 552 & 75 \\
Pesticide mix & 6 & 3 & 570 & 50 \\
Bunker C oil & 10 & 1 & 343 & 10 \\
\hline
\end{tabular}

presented significant increases in virus numbers over the control uninduced samples (Table 4)

Both the PCB mixture and Aroclor 1248 were the most efficient (75\%) in inducing indigenous lysogenic bacteria in the marine environments sampled (Table 5) with an average viral percent increase of $286 \%$ and $552 \%$, respectively. The percent efficiency for each treatment is based on increases in viral abundance alone. Sig- 
nificant viral increases were observed at the West Florida Shelf Gulf of Mexico (Stn 1I), Key West Harbor, and Florida Bay stations (Table 3). Only at the Gulf of Mexico Stn 1I, however, were concomitant decreases in BDC measured (78\%). The African Reef environment was not induced with any of the agents tested. This lack of induction response may again be explained by the metabolic activity of the microorganisms or the toxicity of the agents utilized. While mitomycin $\mathrm{C}$ and the pesticide mixture had relatively lower efficiencies for induction (60 and 50\%, respectively), the average percent viral increase for both agents were greater ( $581 \%$ and $570 \%$ increase, respectively) than that seen when the PCB mixture or Aroclor 1248 were utilized. Fig 2 illustrates a typical field of view when these 2 treatments were observed under TEM. Bunker $\mathrm{C}$ fuel oil \#6 had the lowest efficiency for the induction of marine lysogens with only $10 \%$ of the samples induced and a $343 \%$ average viral increase

\section{DISCUSSION}

A total of 9 stations from a diversity of marine environments, including estuarine, coastal, offshore, and coral reef environments, were examined for the presence of lysogenic bacteria. Samples for 6 (66.7\%) stations showed prophage induction by at least one of the chemicals examined, with the PCB mixture and Aroclor 1248 giving the highest percent efficiency for prophage induction. It should be noted that the detection of inducible lysogens in this study was based on significant increases in viral abundance alone. Previously we determined prophage induction by a concomitant statistically significant increase in VDC and decrease in BDC (Jiang \& Paul 1994, 1996). We have reevaluated this criterion due to the possibility of underestimating the indigenous lysogenic bacterial population. Our justification behind this is that induction may occur even when there are only small changes in total $B D C$. It is difficult to detect small changes in BDC because of the variability in cell counts. A second problem is the variability in VDC, particularly in offshore environments, where low viral abundance results in a larger standard error in TEM VDC (Jiang \& Paul 1996).

In previous reports, we have estimated the percent lysogenic bacteria by 2 methods: (1) the decrease in $\mathrm{BDC}$ in the presence of inductants, and (2) dividing the number of viruses increased by an average burst size (30; Jiang \& Paul 1996). This yields a percentage of lysogenic bacteria of 10.5 to $78.3 \%$ (mean $35 \%$ ) by the former method to between 1.5 and $38 \%$ (mean $8.8 \%$ ) by the latter and present method (Jiang \& Paul 1996). The percentage of bacteria that were lysogenic for all positively induced samples ranged from 1.32 to $121 \%$ (mean $16.8 \%$ ). The high end of this range $(\geq 100 \%$ of the bacteria) may be the result of choosing too low an average burst size for that environment. By ignoring the BDC, this method is not influenced by bacterial mortality caused by the possible toxicity of the inducing agents, and therefore determines the percent of lysogenic bacteria by increases in viral abundance alone. The drawback of this method is that it requires knowledge of the lysogenic burst size. A survey of electron photomicrographs of induction of natural populations yielded a burst size of 30 (Jiang \& Paul 1996).

The efficiency of mitomycin $\mathrm{C}$ as an inducing agent in cultured and indigenous lysogenic bacteria has been well documented (Ackermann \& DuBow 1987 , Jiang \& Paul 1994, 1996). In this study, we showed that mitomycin $C$ had an efficiency rate of $60 \%$, being able to induce lysogenic bacteria in 5 of the 9 stations sampled. Mitomycin $C$ was found to induce prophage at each concentration utilized in marine environments that contained active bacterial communities (coastal and estuarine environments). In oligotrophic or pristine environments such as the Gulf of Mexico Stn $1 \mathrm{C}$ or African Reef, no inducible prophage were detected.

Mitomycin $\mathrm{C}$, however, is not naturally found in the marine environment. Prophage induction occurs when the host cell is exposed to DNA damaging agents, mutagenic agents, or stress conditions which trigger the bacterial cell's 'SOS' response system and cause the induction of the prophage (Ackermann \& DuBow 1987). To understand the environmental factors that cause prophage induction in the marine environment, we tested the effects environmentally important pollutants had on the ability to induce indigenous lysogenic bacteria. We analyzed several agents that can be found in the marine environment due to their use in the agricultural and shipping industry (Sherblom et al. 1995). Using significant increase in viral abundance alone, the PCB mixture and Aroclor 1248 were the most efficient agents $(75 \%)$ for the induction of lysogens. The pesticide mixture and bunker $C$ fuel oil \#6 followed with a $50 \%$ and $10 \%$, respectively, efficiency of these agents to detect inducible lysogens.

In pristine environments such as the African Reef and Marquesas stations, lysogenic bacteria as determined by mitomycin $C$ prophage induction were rarely detected. These 2 pristine, relatively isolated tropical environments possessed tremendous water clarity and were quite different than the Tampa Bay estuary or Key West Harbor. Ackermann \& DuBow (1987) reported that the induction of prophage in cultured bacteria was more efficient with actively growing cultures due to the active replication and DNA repair mechanisms occurring during this time. At the African Reef and Marquesas stations, the bacteria may not be as metabolically active as their counterparts in other 
nearshore environments. However, since no measurement of bacterial activity was made in this study, this explanation is speculative. The bacteria in these pristine environments may also be more sensitive to the toxicity of the inducing agents employed. In coastal and estuarine environments, each pollutant employed resulted in prophage induction. Bunker C fuel oil ( $1 \mu \mathrm{g}$ $\mathrm{ml}^{-1}$ ) was observed to induce lysogenic bacteria found in the Key West Harbor. In a previous study (Jiang \& Paul 1996), no prophage induction was observed with bunker $C$ fuel oil $\left(100 \mu \mathrm{g} \mathrm{ml}^{-1}\right)$, although a high level of bacterial mortality was measured. Only 1 site in 10 experiments resulted in prophage induction. The higher concentrations employed or lack of active bacteria at the other sites may have caused the negative results observed there.

There has been little recent information on the levels of plasticizers and pesticides in the Gulf of Mexico. Most values are from the 1970 s and are for sediments or tissues of organisms. Duke et al. (1970) measured Arochor 1254 in the water column and found a range of 3 to $275 \mathrm{ppb}\left(1 \mathrm{ppb}=1 \mathrm{ng} \mathrm{m} \mathrm{l}^{-1}\right)$. We employed $1 \mathrm{\mu g}$ $\mathrm{ml}^{-1}$ or appoximately $4 \times$ the highest water column. value measured. However, levels in organisms and sediments were reported as high as $184 \mathrm{ppm}\left(\mu \mathrm{g} \mathrm{ml}^{-1}\right)$

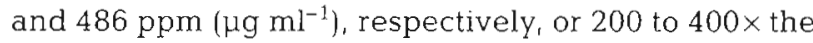
concentration we employed. Thus, bacteria in sediments or in organism tissues might actively be induced by such pollutants. In terms of pesticide levels, DDT in mollusk tissue was as high at $5.39 \mathrm{ppm}$, or $50 \times$ the water column concentration we employed (Butler 1973). In a more recent study of pesticides in coral tissue, the concentrations of DDD, Lindane, heptachlor, dieldrin, endosulfan, endrin, and methoxychor, all components of the pesticide mix employed, ranged from 60 to $2924 \mathrm{ppb}$ (Glynn et al. 1989). Although it is difficult to relate tissue concentrations to water column concentrations, the high end of the range was $29 \times$ the concentration we employed.

In summary, lysogenic bacteria may be an important portion of the marine microbial community. We showed here that many environmentally important pollutants may be inducing agents for natural lysogenic viral production in the marine environment. Of all marine environments, estuaries have been found to contain the greatest viral numbers. This may be caused in part by induction of rapidly growing bacteria found there by pollutants such as those investigated in this study. Alternatively, prophage induction could be caused by natural factors that as yet are not understood.

Acknowledgements. We thank the captain, crew, and marine technicians of the RV 'Pelican' for their excellent performance on the cruise. We also thank Scott Pichard and Jordan Kang for their assistance with the ${ }^{14} \mathrm{C}$ carbon fixation expenments. This research was submitted as partial fulfillment toward a master's degree at the University of South Florida, St. Petersburg. This research was supported in part by grants from the National Science Foundation OCE 9502775 , OCE 9214614. BIR-9512122.

\section{LITERATURE CITED}

Ackermann HW, DuBow MS (1987) Viruses of prokaryotes Vol 1 General properties of bacteriophages. CRC Press, Boca Raton

Barrie LA, Gregor D, Hargrave B, Lake B, Muir D, Shearer R, Tracey B, Bidleman T (1992) Arctic contaminants: sources, occurrence and pathways. Sci Total Environ 122:1-74

Bedard DL, Harberl ML (1990) Influence of chlorine substitution pattern on the degradation of polychlorinated biphenyls by eight bacterial strains. Microb Ecol 20:87-102

Bergh $\varnothing$, Børsheim KY, Bratbak G, Heldal M (1989) High abundance of viruses found in aquatic environments. Nature 340:467-468

Bratbak G, Heldal M, Norland S, Thingstad TF (1990) Viruses as partners in spring bloom microbial trophodynamics. Appl Environ Microbiol 56:1400-1405

Bratbak G, Heldal M, Thingstad TF, Riemann B, Haslund OH (1992) Incorporation of viruses into the budget of microbial C-transfer. A first approach. Mar Ecol Prog Ser 83:273-280

Butler PA (1973) Residues in fish, wildlife, and estuaries: organochlorine residues in estuarine mollusks 1965-72 National Pesticide Monitoring Program. Pest Monitor J 6 $238-273$

Carpenter DJ, Lively JS (1980) Review of estimates of alga] growth using ${ }^{14} \mathrm{C}$-tracer techniques. In: Falkowski PG (ed) Primary productivity in the sea. Plenum Press, New York, p 161-178

Cochran PK, Paul JH (in press) Seasonal abundance of lysogenic bacteria in a subtropical estuary. Appl Environ Microbiol

Duke TW, Lowe JI, Wilson AJ Jr (1970) A polychlorinated biphenyl (Arochlor 1254) in the water, sediment and biota of Escambia Bay, Florida. Bull Environ Contam Toxicol 5 $171-180$

Erikson MD (1986) Analytical chemistry of PCB's. Butterworth Publishers, London

Fuhrman JA, Noble RR (1995) Viruses and protists cause similar bacterial mortality in coastal seawater Limnol Oceanogr 40:1236-1242

Fuhrman JA, Suttle CA (1993) Viruses in marine planktonic systems. Oceanography 6:57-63

Glynn PW, Szmant AM, Corcoran EF, Coffer-Shabica SV (1989) Condition of coral reef cnidarians from the Northem Flonda reef tract: pesticides, heavy metals, and histopathological examination. Mar Pollut Bull 20:568-576

Hara S, Terauchi K, Korike I (1991) Abundance of viruses in marine waters: assessment by epifluorescence and transmission electron microscopy. Appl Environ Microbiol 57 : $2731-2734$

Heldal M, Bratbak G (1991) Production and decay of viruses in aquatic environments. Mar Ecol Prog Ser 104:1703-1709

Holm-Hansen O, Riemann B (1978) Chlorophyll a determination-improvements in methodology. Oikos 30:438-447

Jiang SC, Paul JH (1994) Seasonal and diel abundance of viruses and occurrence of lysogeny/bacteriocinogeny in the marine environment. Mar Ecol Prog Ser 104:163-172

Jiang SC, Paul JH (1996) Occurrence of Jysogenic bacteria in marine microbial communities as determued by prophage 
induction. Mar Ecol Prog Ser 142:27-38

Jiang SC, Thurmond JM, Pichard SL, Paul JH (1992) Concentration of microbial populations from aquatic environments by Vortex Flow Filtration. Mar Ecol Prog Ser 80: $101-107$

McElroy AE, Farrington JW, Teal JM (1989) Bioavailability of polycyclic aromatic hydrocarbons in the aquatic environment. In: Varanasi U (ed) Metabolism of polycyclic aromatic hydrocarbons in the aquatic environment. CRC Press, Boca Raton, FL

Paul JH (1982) The use of Hoechst dyes 33258 and 33342 for the enumeration of attached and pelagic bacteria. Appl Environ Microbiol 43:939-949

Paul JH, Jiang SC, Rose JB (1991) Concentration of viruses and dissolved DNA from aquatic environments by vortex flow filtration. Appl Environ Microbiol 57:2197-2204

Sherblom PM, Kelly D, Pierce RH (1995) Baseline survey of pesticide and PAH concentrations from Sarasota Bay, Florida, USA. Mar Pollut Bull 30:568-573

Sieburth JMcN, Johnson PW, Hargraves PE (1988) Ultrastructure and ecology of Aureococcus anophagefferens gen. et sp. nov. (Chrysophyceae): the dominant picoplankter during a bloom in Narragansett Bay, Rhode

Editorial responsibility: Otto Kinne (Editor),

Oldendorf/Luhe, Germany
Island, summer 1985. J Phycol 24:416-425

Strickland JDH, Parsons TR (1968) A manual of seawater analysis, 2nd edn. Bull Fish Res Bd Can 125:1-311

Thingstad TF, Heldal M, Bratbak G, Dunda I (1993) Are viruses important partners in pelagic food webs? Trends Ecol Evol 8:209-213

Wang DH, Willis DL, Loveland WD (1975) Radiotracer methodology in the biological, environmental, and physical sciences. Prentice-Hall, Englewood Cliffs, NJ

Weinbauer MG, Peduzzi P (1995) Significance of viruses versus heterotrophic nanoflagellates for controlling bacterial abundance in the northern Adriatic Sea. J Plankton Res $17: 1851-1856$

Weinbauer MG, Suttle CA (1996) Potential significance of lysogeny to bacteriophage production and bacterial mortality in coastal waters of the Gulf of Mexico. Appl Environ Microbiol 62:4374-4380

Wilcox RM, Fuhrman JA (1994) Bacterial viruses in coastal seawater: lytic rather than lysogenic production. Mar Ecol Prog Ser 114:35-45

Wommack KE, Hill TT, Kessel M, Tussek-Cohen E, Colwell RR (1992) Distribution of viruses in the Chesapeake Bay. Appl Environ Microbiol 58:2965-2970

Submitted: September 15, 1997; Accepted: January 28, 1998 Proofs received from author(s): March 23, 1998 